\title{
Changes In Some Haematological And Biochemical Parameters of Albino Rats In Response to Low-energy Diet
}

\author{
By. Somaia Z. A. Rashed \\ Tanta University, Faculty of Science, Zoology Department
}

\begin{abstract}
The effect of low-energy diet (Low protein or low fat-diet) was studied using male albino rats. The experiment was expended to 45 days (30 days treatment and 15 days recovery period). Body weight gain or loss as well as blood samples for blood picture (R.B.CS. W.B.C S $_{S}$ count, Hb. concentration, Hct value and erythrocyte indices such as $\mathrm{MCV}, \mathrm{MCH}$ and $\mathrm{MCHC}$ ) well recorded Biochemical examination for glucose concentration, total protein, albumin, globulin and $\mathrm{A} / \mathrm{g}$ ratio. Triglyceride level,

total cholesterol and LDL-cholesterol, and HDL-cholesterol level, in addition to some hormones such as insulin, Testosterone and Leptin levels were examined at the end of the treatment period and the recovery period. A significant decrease in body weight gain percentage was observed in group fed low

protein or Low fat-diet and the body weight improved during and after the recovery period. A significant decrease in R.B.C S $_{\text {, W.B.C }}$, count and $\mathrm{Hb}$. concentration, and Hct value in treatment period and improved during and after recovery period. Total proteins, albumin and globulin were significantly affected by low protein or low-fat diet treatment in comparison with the control group. These effects were significantly counteracted by balanced diet. A significant decrease in triglyceride, total cholesterol, LDL-cholesterol and HDL-cholesterol were observed in groups received diet containing low-protein or low fat as compared with the control group. The results of the present study showed a significant reduction in (Leptin, insulin and testosterone) level after treatment for 30 days and recovery period for 15 days.
\end{abstract}

\section{INTRODUCTION}

There is a widespread interest in dietary protein or fat effect on various aspects of protein and lipid metabolism and problems relating to hepatic and cardiovascular disease. Some problems can develop at the extremes either low fat or low protein intakes. Excess fat causes elevation of serum lipids and thus an increased risk of heart disease and arteriosclerosis, but the low fat diet causes reduction of serum total lipids Also there is a widespread agreement that consumption of food low in protein or low in fat resulted in substantial weight loss. The elegant model of Flatt (1987) predicts that low protein or low fat diet should induce weight loss. Long term trials of low-fat or low protein 


\section{Changes In Some Haematological And Biochemical Parameters}

diets have resulted in decreases in body weight as compared to control group fed balanced diet Lee-Han (1988) and Retzl half (1991).

Low-protein diets are still major pediatric problems in many parts of the world and result in an overall reduction in the growth and development of all major tissues of the body. (Tover et al., 1998). Anaemia is a very common manifestation in low-protein or low fat diet (Fondu et al., 1978). Therefore, the present study aimed to provide additional information on the relationship between the role of low protein or low fat in diet on the haematological parameters and some association (Soheir et al., 1996).

Impaired erythropoietin production was considered one of the reasons for anaemia as mentioned by Tazaki et al. (1994); Zaahkouk and Helal (1999) recoreded a significant decrease in red blood cells count

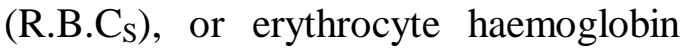
$(\mathrm{Hb})$ concentrations and white blood cells count (W.B.C S $_{\text {) }}$ or leucocyte in rats fed on low-energy diet. Caro et al. (1983) reported that erythropoietin (EPO) is produced not only by the kidneys but also by other organs, such as liver.

The haematological alterations produced after low-energy diet period have been improved greatly after recovery period when the rats fed on balanced diet. The improvements may be attributed to increased protein synthesis after the inclusion of amino acid in the diet and induce synthesis of red blood cells via stimulation of erythropoisis. Also improvement in the immune system by improving the percentages of each kind of leucocytes that meet sustaining body activities (Jacobh et al., 1996).

There was a significant decrease in blood glucose level in response to low-protein and fat diets Davalose et al., (1996) and Zaahkouk and Helal,
(1991) postulated that the decrease in serum glucose of low-energy diet may be due to decrease gluconeogenesis, depletion of liver glycogen and increased utilization of glucose by tissue. The decrease in total protein, albumin and globulin in low-protein diet might be due to the depletion of daily requirements of amino acids and consequently the disturbance in protein synthesis. The same results were recorded by Zaahkouk and Helal (1999).

Hypotriglyceridemia was evident in low-fat diet due to decrease in the rate of synthesis of very low denisty lipoprotein (VLDL) the main triacylglycerol carrier, and its secretion from the liver to the circulation and correlated to the rate of lipid biosynthesis in the hepatic tissue particularly triacylglycerol (Dietschy et al., 1978). Hypocholesterolemia was evident in all treated rats with low protein or low fat diet. To reduce plasma cholesterol concentration and the risk of coronary heart disease, recent recommendations have suggested that fat man intake of saturated fats should be reduced to below $10 \%$ of dietary energy (Men Sink, 1992). Sally et al. (1997) showed that low-fat diet enriched with olive oil provides advantages over a very low-fat diet in the control of serum lipoproteins among persons with hypercholesterolemia.

Katan (1997) concluded that there are some indications that high carbohydrates, high fibres and low-fat diets may help to produce ischemic heart disease in diabeties and obesity. Hypercholesterolemia has been

identified as a major risk factor of coronary artery disease (Neaton, 1992). Thus, reduction in concentration of total serum cholesterol, and low-denisty lipoprotein (LDL-cholesterol) have 


\section{Somaia Z. A. Rashed}

been shown to decrease the risk for future coronary events.

Because serum cholesterol concentration can be lowered by altering intakes (Grundy et al., 1990) and Dwyer (1995). It has been recommeded generally that dietary fibre intake be increased but variable emphasis has been given to fibresLipids lowering effects (Mekky 1997). One reason low-fat diets have such appeal is that they are thought to prevent weight gain.

Adult population groups, that subsist on low-fat diets are often lean, and this may cancel out the effect of such diet on high density lipoproteincholesterol (HDL-cholesterol). To maintain weight loss, it may be physiologically necessary for successful weight loss mainteners to consume a lower-energy and lower-fat diet than persons who have been obese as recorded by Siao Mei, (1998).

Low-fat diet reduces the risk of cardiovascular disease, generally and is accepted to be a consequence of a decrease in circulating levels of LDL and HDL-cholesterol. Concentrations (William et al., 1999).

Chronic low-energy diet is one of the most important causes of several metabolic daysfunctions such as hypoinsulinemia, hypoleptinemia and hypotestosteronemia. A positive correlation exists between leptin and insulin as well as between leptin and testosterone (Baranowska et al., 1999). Leptin, the protein product hormone of the ob/gene (Zhang et al., 1994) is produced in adipose tissue and synthesised in ovary, transported in the oocyte, and made by both fetus and placenta (Hima, 1999).

Also leptin occurs in the lung, kidney, heart, brain, spleen, liver, and muscle (Daniel et al., 1998). Leptin is thought to be an inhibitor to appetite. In addition leptin may have a role in erythropoiesis (Young et al., 1997). Thus Benett et al. (1996) reported a near significant positive correlation between serum leptin and haemoglobin level. Serum leptin is related significantly to body fat content, patients with congenital defeciency of leptin have severe morbid obesity starting in early chilhood (Montague et al., 1997).

Hyperinsulinemia have shown an effect on leptin regulation and is related to acute change in nutritional status. (Dugogo et al., 1996). In support long term insulin infusion, via a direct trophic effect of insulin on the adipocyte, increase leptin secretion (Kolaczynski et al., 1996). The present study was planned to investigate the effect of low-protein or low-fat diet on blood picture and some biochemical parameters of male albino rats.

\section{MATERIAL AND METHODS}

Thirty male albino rats of similar age and weight, weighing $150 \pm 10 \mathrm{gm}$ at the beginning of the experiment were used. All animals were provided free access to tap water throughout the study and were maintained in a temperature-controlled environment $\left(22-25^{\circ} \mathrm{C}\right)$ with a $12 \mathrm{~h} / 12 \mathrm{~h}$ light/dark cycle. All rats were randomly divided into 3 main groups as follows.

1- First group $(n=10)$ was fed the control diet (CD) consisting of $22 \%$ protein (casein), corn starch 60\%, cellulose, $5 \%$ soybean oil $7 \%$, ineral mixture $3 \%$ and vitamin mixture $3 \%$.

2- Second group was fed low protein diet (LPD) consisting of $4 \%$ protein (casein), 78\% corn starch, 5\% cellulose, $7 \%$ soybean oil, $3 \%$ 


\section{Changes In Some Haematological And Biochemical Parameters}

mineral mixture, and 3\% vitamin mixture.

3- Third group was fed low fat diet (LFD) consisting of $4 \%$ fat (corn oil), $78 \%$ corn starch, $5 \%$ cellulose, $7 \%$ sucrose, $3 \%$ mineral mixture and $3 \%$ vitamin mixture.

The treatment diets nearly isocalori, thus the only dietary variable altered was protein and fat. Food consumption and spillage were measured to the nearest $0.1 \mathrm{~g}$. Each 5 rats were housed in a separated cage so that food consumption and body weight could be measured daily. Body weight was measured in the nearest gram using triple beam balance. Daily weighing ensured that there were no health problems occurring in rats fed the low protein or low fat diet and provided data for subsequent analysis.

After 30 days of treatment, five animals of each group were decapitated, while the other half of each group was kept for 15 days for recovery period and fed control or balanced diet. Blood samples were collected in two centrifuge tubes, one containg anticoagulant for haematological analysis and the second tube devoid any anticoagulant and centrifuged for 20 minutes at $4000 \mathrm{rpm}$. Serum was collected and transfered into another clean tube for biochemical analysis.

Haematological parameters include: red blood cell count (R.B.C S $_{\mathrm{S}}$ ) and white blood cells count (W.B.C S $_{S}$ ) according to the method of Dacie and Lewis (1991), Haemoglobin (Hb) concentration was measured according to the method of Drabkin and Austin (1932). Haematocrit (Hct) value was determined by the method of Rodak (1995) using heparinized capillary tubes and erythrocyte indices according to the method of Rodack (1995).

Biochemical parameters include: glucose, concentration was determined in serum by using the method of Trinder
(1969), total protein level was measured colorimetrically using commercial available kit according to Doumas (1975) method, Albumin concentration was estimated by using the method of Doumas et al (1971) using commercial available kit.

Globulin level in serum was calculated by subtracting albumin from total protein, triglycerides concentration in serum was colorimetrically measured by using the method of wahlefeld (1974), using Boehringer Mannheim (GmbH Diagnostica Kit). Total cholesterol was determined according to the method of Allain et al. (1974). Low denisty lipoprotein-cholesterol (LDLcholesterol) was colorimetrically estimated by using the method of Friedwald et al. (1972). Also high denisty lipoprotein-cholesterol was measured according to the Benzie (1979) method.

LDL-Cholesterol, = Total cholesterol $\frac{\text { Triglyceide }}{5}-$ HDL -cholesterol

Insulin concentration in serum was measured by radio-immunoassay kit obtained from D.P.C. Los angeles, according to the method of Reeves (1983). Leptin level in serum was measured according to MaZognium et al. (1996). Serum testosterone concentration was carried out using the method of Dolacardo et al. (1973). Statistical analysis: The statistical analysis of the obtained data was done according to Armitage (1974).

\section{RESULTS}

It is clear that the percentage change of body weight gain or loss as indicated in table (1) and figure (1) was $25 \%$ of change in group received diet containing low-protein diet and 50\% of change in group received low fat diet 


\section{Somaia Z. A. Rashed}

after 30 days of treatment as compared to balanced diet or control group. After 15 days of recovery period by balanced or control diet the percentage of change 20 and 36 in group received diet containing low-protein or low-fat diet respectively.

As for haematological param eters, R.B.C. $\mathrm{C}_{\mathrm{S}}$ and W.B.C $\mathrm{C}_{\mathrm{S}}$ count, $\mathrm{Hb} \%$ concentration, Hct value and erythrocyte indices (MCV, $\mathrm{MCH}$ and $\mathrm{MCHC}$ ) results are presented in table (2) and figure (2). Remarkable changes were observed. R.B.C $\mathrm{C}_{\mathrm{S}}$ count and $\mathrm{Hb}$ concentration were lowered in case of the group receiving low-protein or lowfat diet during the treatment period and insignificant change after recovery period. Also W.B.C s $_{\mathrm{s}}$ significantly decreased only in the group receiving low-protein diet as observed in table (2) and figure (2).

Investigation of other haemat ological indices revealed that the two low-energy diets caused significant reduction in the mean corpuscular volume (MCV). The mean corpuscular haemoglobin $(\mathrm{MCH})$ showed no significant change, while the mean corpuscular haemoglobin concentration (MCHC) was significantly decreased as compared to the control group.

Table (3) and figure (2) represent serum glucose concentration in the group of rats receiving low-

protein or low-fat diet for 30 days treatment. Results showed a significant $(\mathrm{P}<0.01)$ reduction as compared to the group fed on control or balanced diet. As shown in table (2) and figure (2) low-protein diet revealed a signification $(\mathrm{P}<0.05)$ decrease in total protein after 30 days of treatment and this decrease was improved after recovery period. Both serum albumin and serum globulin showed a significant decrease $(\mathrm{P}<0.05)$ in the group fed low-protein diet.

Hypolipidema was evident after 30 days of treatment by receiving diet containing low-protein or low-fat diet, therefore a significant $\quad(\mathrm{P}<0.05)$ decrease was shown in circulating triacylglycerolemia whereas circulating concentrations of total cholesterol were significantly $(\mathrm{P}<0.01)$ decreased as shown in table (2) and figure (2). The increase in circulating cholesterol was evident in HDL-cholesterol, the main cholesterol carrier lipoprotein in rat after treatment period 30 days. However LDL-cholesterol levels were significantly below the control level after 30 days of treatment period.

The present data concerning hormones, insulin, leptin and testosterone as observed in table (4) and figure (3) showed a significant decrease $(\mathrm{P}<0.05)$ in insulin level in the group which received low-protein or low-fat diet for 30 days and improved after recovery period 15 days by balanced diet. Hypoleptinemia was observed in the group receiving low-fat diet. Also there is a significant $(\mathrm{P}<0.0)$ reduction in testosterone hormone in the group receiving low-protein or low-fat diet. A positive correlation between insulin and leptin hormone as well as a correlation was found between leptin and testosterone concentrations and low-fat diet or type of diet.

\section{DISCUSSION}

From the present data, all animals that received low-protein or low-fat diet were observed to have lesser body weight than control or the group fed balanced diet. Low-energy diet leads to decrease in body weight that may be attributed to or in part by the decrease in insulin-like growth factor-1(1Gf-1) levels as has been 


\section{Changes In Some Haematological And Biochemical Parameters}

reported by keteslegers et al. (1995). The most consistent predictors of greater weight loss were low-intake of dietary fat, higher initial waist circumference, and higher levels of moderate intensity physical activity Besbas et al. (1998).

The lower the achieved fat intake, the greater the initial and sustained weight loss. Hill et al. (1993) postulated that the magnitude of the energy deficit rather, than the cause of the deficit is the most important factor in initiating weight loss. In contrast, a specific reduction in the dietary fat intake is likely, to be most important in achieving sustained weight loss because it counteracts the decline in fat oxidation after weight loss (Hill et al., 1993). These data suggest that the successful weight loss maintainers consume less energy and a lower percent of dietary energy from fat (Siao Mei et al., 1998).

Alterations of various haematological parameters in blood of the present work were also investigated. When rats were fed low-protein or lowfat, diet for 30 days exhibited significant decrease in both red blood cells (R.B.C S $_{S}$ and white blood cells

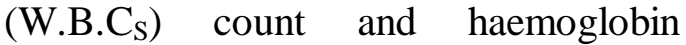
concentration. These findings were in agreement with Fondu et al. (1978) and Soheir et al. (1996). The early response to chronic changes in blood volume in haemodilition. These help to maintain

the circulating blood volume but cannot replace the R.B.C. S. So drop in erythrocyte count will occur. These results were in agreement with Zaakhouk et al (1999) who reported that the low-fat diet cause anaemia and decrease in haematocrit value (Hct) which may be due to increased plasma volume and decrease in blood corpuscle relatively. The present results also demonstrated significant reduction in
Hct, MCV, and MCHC while $\mathrm{MCH}$ revealed no significant change as compared to control group. This may lead to anaemia as a result of iron and globin deficiency.

Low-energy diet decreases blood glucose level due to decreased gluconeoge -nesis, depletion of liver glycogen and increased utilitzation of glucose by tissues. Traianedes et al., (1992) found that fasting glucose level in diabetic rats fed high fat diet was markedly higher relative to those fedlow fat diet.

The present investigation indicated that concentration of serum total protein, albumin and globulin in groups that received low-fat or low protein diet significantly $(\mathrm{P}<0.05)$ decreases. These data were in agreement with that of Zaahkouk et al., (1999), who recorded that the marked decrease observed is probably due to disruption of lepatic cells, a decline in serum protein and level was noticed as a physiological response to malabsorption or low-energy diet.

In the current study, low-protein or low fat diet exhibited marked serum hypotriglycridemia characterized by decreased serum triglycerides due to the low rate of synthesis of VLDL, the main triglyceride carrier and its secretion from the liver to the circulation and correlated to the low rate of lipid biosynthesis in the hepatic tissue particularly triacylglycerol (Dietschy et al., 1978).

Hypocholesterolemia was evident in the group fed low-fat diet and the group that received diet containing low protein diet. Hypercholesterolemia has been identified as a major risk factor of coronary artery disease (Neaton 1992). Thus, reduction in total serum cholesterol and LDL-cholesterol which accounts for most of the cholesterol in the blood. It carries cholosterol to the tissue of the body 


\section{Somaia Z. A. Rashed}

including the arteries. For this reason a high level of LDL-cholesterol increases the risk of dangerous build up and blockage in the arteris (Assmann, 1982)

Low-fat diet reduces the risk of cardiovascular disease, chronic low energy diet is one of the most important causes of several metabolic dysfunction, HDL-cholesterol is sometimes called the good cholesterol because it contains a relatively small amount of cholesterol itself and carries a way harmful fatty deposits from cells and tissues to the liver for excretion from the body. This help to prevent the build up of cholesterol in the wall of arteries (Assman N.G., 1982).

Human insulin is a polypeptide hormone originating in the beta cells of the pancreas and serving as a principal regulator for the storage and production of carbohydrates. Its secretion is normally stimulated by increases in the

\section{REFERENCES}

Allain, C.C., Lucy, S.P.; Cicely, S.G.C., Richmond, W. and Paul, C.F. (1974): Enzymatic determination of total serum cholesterol. clin. chem., 20 (4) : 470-475.

Armitage P. (1974): Statistical method in medical research. Black well scientific pub. Oxford, London. pp. 116-120.

Assmann. G., (1982): Biochemistry of protein in : - Lipid metabolism and atherosclerosis pp. 14. f.n. Schattaur verlag GmbH Stuttgust Germany.

Baranowska, B.; Radti kowska, H.; Waselwisk S.; Kaplin/Ski A.; Raquski K, and plonowski A., (1999) Gynecol. Endocrinol. 13(5): 344-351.

Benzie, L. (1979): Measurement of high denisty lipoprotein cholesterol in serum (H.DL-cholesterol\123456). Med. Lab Sci. 36: 289-291. amount of glucose in circulation. This leads to higher insulin levels and more rapid tissue assimilation of glucose followed by a decline in the insulin level as the glucose level subsides. Low-fat diet decreases insulin secretion as recorded by Plagmann et al. (1999). These results were obtained by Nagatani et al. (1998). Low-fat diet led to Hypoleptinemia, Hypothalamic neuropeptide Y (NPY) neurons are influenced by circulating level of insulin and leptin and are thought to be involved in mediating hunger following undernutrition (Pick Kavance 1998). The decrease in the testosterone level is expected to be effect of the biological activity of sertoli cells or may be attributed to leydig cells exhaustion (Dyme 1983) which is affected by lowenergy diet or the interstitial tissues decreased capacity to synthesize, testosterone (Yogeu et al., 1985).

Besbas N. Ozdemir S.; Saatci U.; Coskun T.; Ozen S.; Topaloglu R.; Bakkaloglu A. and El Nahas A.M. (1998): Nutrition assessment of children on haemodialysis: value of IGF-I and Dialysis. Transplantation., 1316: 14841488.

Caro.L; Zin, L.I.; Silver, R.; Miller, O. and Erslev, A.I. (1983): Erythropoietin in liver tissue extracts and in liver perfusates from hypoxia rats. Am. J. physiolo., 244: E 431-E 434.

Dacie, J.V. and Lewis, S.M. (1991): Haematology 7 th ed. english language book society and churchill living ston, pp. 37-58.

Davalas, A.; Ricart, W.; Gonzalez, H.F.; Soler, S.; Marrugnt, J.; Molins, A.; Suner, R. and Genis, D. 1996. Effect of malnutrition after acute stroke on clinical outcome. Stroke, 27(6): 1028-1032. 


\section{Changes In Some Haematological And Biochemical Parameters}

Dietschy, J.M., Gotto, A.M. and Ontko J.A. (1978): Disturbances in lipid and lipoprotein metabolism. Am. Physiol. Soc. 30: 200-205.

Dolacardo L.; Kawarnski, A.L., Athancalo W.R.; Migean, C.H., (1973): Integrated concentration and circulation variation of plasma testosterone in normal man. J Clin. Endocrinol. Metabol. 37-366-371.

Doumas, B.T. (1975): Standard for total serum protein assays. Clin. chem., 21 (8): 1159-1166.

Doumas, B.T., Watson, W.A. and Biggs, H.G., (1971): Albumin standars and measurements of serum albumin with bromocresol green. Clin. Chem. Acta., 31: 87-96.

Drabkin, D.L., and Austin, 7 H. (1932): Spectrophotometric studies: spectrophotometric constants for common hemoglobin derivatives in human, dogs and rabbit, 7. Biol. Chem., 98: 719-725.

Dyme M. (1983): The male reproductive system in: Histology. cell and tissue biology 5th ed. Edited by Weiss L. pp. $1030 \mathrm{El}$ sevier science publishign co. inc. New York.

Fondu, P.; Nagu, P. and Halvorsen, S. (1978): The regulation of erythropoiesis in protein energy. malnutrition. Brit. Z. haemt., 38: 29-36.

Friedwald, W.I., Levy, R.I. and fried Rickson, D.S. Estimation of the concentration of the low denisty lipoprotein cholesterol in plasma without use of the preparative ultracentrifuge. Clin. Chem. 18: 495-502.

Hill J.O.; Drougas H. and Peters J.C. obesity treatment: Can diet composition play a role. Ann Inter. Med., 119: 894-897.

Jacob R.; Niederstock, D.; Hasan, S.; NcNullty, P.H.; Shewin, R.S., and Young L.H. (1996): Insulin-GrowthFactor. I stimulation of muscle protein synthesis in the rats: Am. J physiol., 270: 60-66.

Keteslegers, J.M.; Maiker D.; Maes, M.; Underwood, L.E. and Thissen, J.P., (1995): Nutritional regulation of insulin-like growth factor -1 : Metabolism, 10: 50-57.

Mazogniun, E.A. (1996): Radioimunnoassay of Leptin in human plasma. Clinical chemistry 42: 942-946.

Nagatani S.; Ciulthi Konde P.; Thomboon R., C.; Tsukamura H., Naeda K.1. and poster D.L. (1998): Evidence for $\mathrm{Cn} \mathrm{RH}$ regulation by leptin. Leptin administration prevents reduced pulsatile LH secretion during fasting. Neuroendocrinology 67(6): 370-476.

Pick Kavance L.C.; Wideeowson P.S.; Vornon, R.G.; and Willian F. (1998): Neuropeptide Y receptor alterations in the hypothalamus of Lactating rats peptides 90(8): 1055-1060.

Plagemann P.; Hardes T; Rake A., Waas.T Melchior K.; Zika Rohde W. and Dorner C. (1999): Observations on the orexigenic hypothalamic neutropeptide overfed weanting rats. J. Neuroendocrinology 11(7): 541-546.

Reeves, W.G. (1983): Insulin antibody determination theoretical and practical consideration, Diabetologia, 24:3390403.

Rodak, L.C., (1995): Routing testing in hematology, in: Diagnostic chematology, W.B. Saunders company philadelphia, London, Toronto pp.128-144. Siao Mei, M.S.; Rena, R.W.; Mary., L.K.; Moureen T. Mo. Cure, James, O., H.; and Helen, S., (1998): Persons successful at long-term weight loss and maintenance containue to consume a low-energy, low-fat-diet: J. Am. Diet

Associat. 98C4): 408-413.

Soheir, L.S.; Khodiga, G. and Soheir, O.E. 1996): Evaluation of serum ferritin in Egyptian children with protein- 
energy malnutrition.

Tasaki, T.; Ohto, H., Noguchi, M.; Motoki, R.; Kikuchi, S.; Sato, A, and Hoshino, S. (1994): Iron and erythropoietin measurement in autologous blood donors with anemia. Transfusion, 34(4): $\quad$ 337-343.

Traianedes, K.; Proietto, J. and O'Dea; K. (1992): A high fat diet metabolic control in streptozotocin treated rats by increasing hepatic glucose production. Metab., clin and Experi, 41: 846-850.
Trinder, P., (1969): Determination of glucose in blood using glucose oxidase with an alternative acceptor, Ann. Clin. Biochem., 6624-27.

Wahlefeld, A.W. (1974): Triglycerides determination after enzymatic hydrolysis in: Method of enzymatic analysis. Verlag and Weinheim publ. Co., New York and London.

Zaahkouk, S.A.M., and Helal E.G. (1999): Effect of malnutrition on some physiological aspects in young rats. J. Egypt. Ger. Soc. Zool. 28(A). Comp. physiol. 27-41.

Table (1): Mean values of body weight changes of male albino rats fed on lowenergy diet for 30 days treatment and 15 days recovery period.

\begin{tabular}{|l|l|l|l|l|l|l|}
\hline \multirow{2}{*}{} & \multicolumn{3}{|c|}{ Treatment period 30 days } & \multicolumn{3}{c|}{ Recovery period 15 days } \\
\cline { 2 - 7 } & Control & L.P.D. & L.F.D. & Control & L.P.D. & L.F.D. \\
\hline & 180 & 155 & 130 & 185 & 165 & 149 \\
$\begin{array}{l}\text { Percentage } \\
\text { of change }\end{array}$ & & 25 & 50 & & 20 & 36 \\
\hline
\end{tabular}


Changes In Some Haematological And Biochemical Parameters

Table (2) : Mean values of haematological parameters of male albino rats fed on low-energy diet for 30 days treatment and 15 days recovery.

\begin{tabular}{|c|c|c|c|c|c|c|c|}
\hline \multirow{2}{*}{\multicolumn{2}{|c|}{ Parameters }} & \multicolumn{3}{|c|}{ Treatment period 30 days } & \multicolumn{3}{|c|}{ Recovery period 15 days } \\
\hline & & \multirow{2}{*}{\begin{tabular}{|l|} 
Control \\
6.5 \\
0.12
\end{tabular}} & \multirow{2}{*}{\begin{tabular}{|l} 
L.P.D. \\
4.5 \\
0.2 \\
$* *$
\end{tabular}} & \multirow{2}{*}{\begin{tabular}{|l|} 
L.F.D. \\
5.1 \\
0.3 \\
$*$
\end{tabular}} & \multirow{2}{*}{$\begin{array}{l}\text { Control } \\
6.4 \\
0.15\end{array}$} & \multirow{2}{*}{\begin{tabular}{|l} 
L.P.D. \\
5.5 \\
0.18 \\
$*$
\end{tabular}} & \multirow{2}{*}{\begin{tabular}{|l} 
L.F.D. \\
6.1 \\
0.2 \\
insig
\end{tabular}} \\
\hline $\begin{array}{l}\text { R.B.C.C } \mathrm{x} \\
10^{6} \\
\text { Cell } / \mathrm{mm}^{3}\end{array}$ & \begin{tabular}{|l} 
Mean \\
+ \\
S.E \\
propability
\end{tabular} & & & & & & \\
\hline $\mathrm{Hb} . \mathrm{g} \%$ & $\begin{array}{l}\text { Mean } \\
\pm \\
\text { S.E } \\
\text { propability }\end{array}$ & $\begin{array}{l}16.1 \\
1.1\end{array}$ & $\begin{array}{l}12.5 \\
1.3 \\
* * \\
\end{array}$ & $\begin{array}{l}13.5 \\
1.2 \\
* \\
\end{array}$ & $\begin{array}{l}15.9 \\
1.9\end{array}$ & $\begin{array}{l}14.5 \\
2.0 \\
\text { insig }\end{array}$ & $\begin{array}{l}15.0 \\
2.1 \\
\text { insig }\end{array}$ \\
\hline $\begin{array}{l}\text { W.B.C }{ }_{S} \text { X } \\
10^{3} \\
\text { Cell } / \mathrm{mm}^{3}\end{array}$ & $\begin{array}{l}\text { Mean } \\
\pm \\
\text { S.E } \\
\text { propability }\end{array}$ & $\begin{array}{l}9.5 \\
1.1\end{array}$ & $\begin{array}{l}7.2 \\
1.0 \\
* \\
\end{array}$ & $\begin{array}{l}7.5 \\
1.0 \\
\text { insig } \\
\end{array}$ & $\begin{array}{l}9.6 \\
1.5\end{array}$ & $\begin{array}{l}8.5 \\
1.2 \\
\text { insig }\end{array}$ & $\begin{array}{l}8.0 \\
1.0 \\
\text { insig } \\
\end{array}$ \\
\hline Het $\%$ & $\begin{array}{l}\text { Mean } \\
\pm \\
\text { S.E } \\
\text { propability }\end{array}$ & $\begin{array}{l}42.0 \\
0.9\end{array}$ & $\begin{array}{l}36.1 \\
0.9 \\
* * \\
\end{array}$ & $\begin{array}{l}38.2 \\
1.2 \\
* \\
\end{array}$ & $\begin{array}{l}41.5 \\
1.3\end{array}$ & $\begin{array}{l}38.1 \\
0.9 \\
* \\
\end{array}$ & $\begin{array}{l}40.0 \\
1.5 \\
\text { insig } \\
\end{array}$ \\
\hline $\mathrm{MCV} \mu^{3}$ & $\begin{array}{l}\text { Mean } \\
+\frac{+}{\text { S.E }} \\
\text { propability }\end{array}$ & $\begin{array}{l}64.6 \\
2.5\end{array}$ & $\begin{array}{l}80.2 \\
2.6 \\
\text { insig }\end{array}$ & $\begin{array}{l}74.9 \\
2.6 \\
\text { insig }\end{array}$ & $\begin{array}{l}64.7 \\
2.0\end{array}$ & \begin{tabular}{|l}
69.3 \\
2.1 \\
insig
\end{tabular} & $\begin{array}{l}65.6 \\
2.0 \\
\text { insig }\end{array}$ \\
\hline $\begin{array}{l}\mathrm{MCH} \\
\mathrm{Pg}\end{array}$ & $\begin{array}{l}\text { Mean } \\
\pm \\
\text { S.E } \\
\text { propability }\end{array}$ & $\begin{array}{l}24.7 \\
1.2\end{array}$ & $\begin{array}{l}27.7 \\
0.9\end{array}$ & $\begin{array}{l}26.4 \\
0.7\end{array}$ & $\begin{array}{l}24.8 \\
1.2\end{array}$ & $\begin{array}{l}26.4 \\
1.0 \\
\text { insig }\end{array}$ & $\begin{array}{l}24.6 \\
1.1 \\
\text { insig }\end{array}$ \\
\hline $\mathrm{MCHC} \%$ & $\begin{array}{l}\text { Mean } \\
\pm \\
\text { S.E } \\
\text { propability }\end{array}$ & $\begin{array}{l}38.1 \\
1.0\end{array}$ & $\begin{array}{l}34.6 \\
1.2 \\
\mathrm{P}<0.05\end{array}$ & $\begin{array}{l}35.3 \\
0.9 \\
P<0.05\end{array}$ & $\begin{array}{l}38.3 \\
1.7\end{array}$ & $\begin{array}{l}39.1 \\
1.2 \\
\text { insig }\end{array}$ & $\begin{array}{l}37.5 \\
1.3 \\
\text { insig } \\
\end{array}$ \\
\hline
\end{tabular}

L.P.D $=$ Low-protein diet

L.F.D $=$ Low-fat diet 
Somaia Z. A. Rashed

Table (3): Mean values of biochemical parameters of male albino rats fed on lowenergy diet for 30 days treatment and 15 days recovery.

\begin{tabular}{|c|c|c|c|c|c|c|c|}
\hline \multirow{2}{*}{\multicolumn{2}{|c|}{ Parameters }} & \multicolumn{3}{|c|}{ Treatment period 30 days } & \multicolumn{3}{|c|}{ Recovery period 15 days } \\
\hline & & \multirow{2}{*}{\begin{tabular}{|l|} 
Control \\
100 \\
1.6
\end{tabular}} & \multirow{2}{*}{$\begin{array}{l}\text { L.P.D. } \\
80 \\
1.5 \\
P<0.01 \\
\end{array}$} & \multirow{2}{*}{\begin{tabular}{|l|} 
L.F.D. \\
75 \\
1.7 \\
$\mathrm{P}<0.01$
\end{tabular}} & \multirow{2}{*}{\begin{tabular}{|l|} 
Control \\
95 \\
2.0
\end{tabular}} & \multirow{2}{*}{\begin{tabular}{|l|} 
L.P.D. \\
89 \\
1.5 \\
P $<0.01$ \\
\end{tabular}} & \multirow{2}{*}{\begin{tabular}{|l|} 
L.F.D. \\
85 \\
1.8 \\
$\mathrm{P}<0.01$ \\
\end{tabular}} \\
\hline $\begin{array}{l}\text { Glucose } \\
\mathrm{mg} / \mathrm{dL}\end{array}$ & $\begin{array}{l}\text { Mean } \\
\frac{ \pm}{S} . E \\
\text { propability }\end{array}$ & & & & & & \\
\hline $\begin{array}{l}\text { Total } \\
\text { protein } \\
\mathrm{g} / \mathrm{dL}\end{array}$ & $\begin{array}{l}\text { Mean } \\
\dot{t} \\
\text { S.E } \\
\text { propability }\end{array}$ & $\begin{array}{l}6.5 \\
0.5\end{array}$ & $\begin{array}{l}4.5 \\
0.6 \\
\mathrm{P}<0.05 \\
\end{array}$ & \begin{tabular}{|l}
5.9 \\
0.9 \\
insig \\
\end{tabular} & $\begin{array}{l}5.8 \\
1.0\end{array}$ & \begin{tabular}{|l}
5.5 \\
0.8 \\
insig \\
\end{tabular} & $\begin{array}{l}6.0 \\
0.9 \\
\text { insig } \\
\end{array}$ \\
\hline $\begin{array}{l}\text { Albumin } \\
\mathrm{g} / \mathrm{dL}\end{array}$ & $\begin{array}{l}\text { Mean } \\
\frac{ \pm}{\text { S.E }} \\
\text { propability }\end{array}$ & $\begin{array}{l}3.8 \\
0.1\end{array}$ & $\begin{array}{l}3.0 \\
0.2 \\
P<0.05\end{array}$ & $\begin{array}{l}3.0 \\
0.1 \\
\mathrm{P}<0.05\end{array}$ & $\begin{array}{l}3.6 \\
0.1\end{array}$ & $\begin{array}{l}3.0 \\
0.2 \\
\mathrm{P}<0.05\end{array}$ & $\begin{array}{l}3.5 \\
0.05 \\
\text { insig }\end{array}$ \\
\hline $\begin{array}{l}\text { Globulin } \\
\mathrm{g} / \mathrm{dL}\end{array}$ & $\begin{array}{l}\text { Mean } \\
+\frac{}{S} . \mathrm{E} \\
\text { propability }\end{array}$ & $\begin{array}{l}2.7 \\
0.1\end{array}$ & $\begin{array}{l}1.5 \\
0.07 \\
\mathrm{P}<0.01 \\
\end{array}$ & \begin{tabular}{|l}
2.9 \\
0.03 \\
insig \\
\end{tabular} & \begin{tabular}{|l|}
2.9 \\
0.01
\end{tabular} & \begin{tabular}{|l}
2.5 \\
0.02 \\
insig \\
\end{tabular} & $\begin{array}{l}2.5 \\
0.03 \\
\text { insig } \\
\end{array}$ \\
\hline $\begin{array}{l}\mathrm{A} / \mathrm{G} \\
\text { ratio }\end{array}$ & $\begin{array}{l}\text { Mean } \\
\frac{ \pm}{S} . E \\
\text { propability }\end{array}$ & $\begin{array}{l}1.4 \\
0.01\end{array}$ & $\begin{array}{l}1.3 \\
0.03 \\
\mathrm{P}<0.05\end{array}$ & $\begin{array}{l}1.0 \\
0.01\end{array}$ & \begin{tabular}{|l|}
1.3 \\
0.04
\end{tabular} & \begin{tabular}{|l|}
1.2 \\
0.01
\end{tabular} & $\begin{array}{l}1.4 \\
0.02\end{array}$ \\
\hline $\begin{array}{l}\text { Triglyceridy } \\
\mathrm{e} \\
\mathrm{mg} / \mathrm{dL}\end{array}$ & $\begin{array}{l}\text { Mean } \\
\pm \underline{\text { S.E }} \\
\text { propability }\end{array}$ & $\begin{array}{l}115.0 \\
1.8\end{array}$ & $\begin{array}{l}105.0 \\
2.1 \\
\mathrm{P}<0.05\end{array}$ & $\begin{array}{l}80 \\
2.3 \\
\mathrm{P}<0.05 \\
\end{array}$ & $\begin{array}{l}108 \\
2.0\end{array}$ & $\begin{array}{l}100 \\
1.6 \\
\mathrm{P}<0.05 \\
\end{array}$ & $\begin{array}{l}89 \\
2.1 \\
\mathrm{P}<0.01 \\
\end{array}$ \\
\hline $\begin{array}{l}\text { Total } \\
\text { cholesterol } \\
\mathrm{mg} / \mathrm{dL}\end{array}$ & $\begin{array}{l}\text { Mean } \\
\underline{+} \\
\text { S.E } \\
\text { propability }\end{array}$ & $\begin{array}{l}106.1 \\
1.5\end{array}$ & $\begin{array}{l}90.4 \\
1.2 \\
\mathrm{P}<0.01 \\
\end{array}$ & $\begin{array}{l}80 \\
1.3 \\
\mathrm{P}<0.01 \\
\end{array}$ & $\begin{array}{l}104 \\
1.4\end{array}$ & $\begin{array}{l}96 \\
1.2 \\
\mathrm{P}<0.05 \\
\end{array}$ & $\begin{array}{l}98 \\
1.4 \\
P<0.05 \\
\end{array}$ \\
\hline $\begin{array}{l}\text { LDL.chole- } \\
\text { stetrol } \\
\mathrm{mg} / \mathrm{dL}\end{array}$ & $\begin{array}{l}\text { Mean } \\
\pm \\
\text { S.E } \\
\text { propability }\end{array}$ & $\begin{array}{l}106.1 \\
1.5\end{array}$ & $\begin{array}{l}90.4 \\
1.2 \\
\mathrm{P}<0.01 \\
\end{array}$ & $\begin{array}{l}60 \\
1.3 \\
\mathrm{P}<0.01 \\
\end{array}$ & $\begin{array}{l}104 \\
1.4\end{array}$ & $\begin{array}{l}90 \\
1.2 \\
\mathrm{P}<0.01\end{array}$ & $\begin{array}{l}80 \\
1.1 \\
\mathrm{P}<0.01 \\
\end{array}$ \\
\hline $\begin{array}{l}\text { HDL.chole- } \\
\text { stetrol } \\
\mathrm{mg} / \mathrm{dL}\end{array}$ & $\begin{array}{l}\text { Mean } \\
\underline{ \pm} \\
\text { S.E } \\
\text { propability }\end{array}$ & \begin{tabular}{|l}
53.5 \\
1.6
\end{tabular} & $\begin{array}{l}60.4 \\
1.2 \\
\mathrm{P}<0.05 \\
\end{array}$ & $\begin{array}{l}76 \\
1.5 \\
\mathrm{P}<0.01 \\
\end{array}$ & $\begin{array}{l}54.0 \\
2.5\end{array}$ & \begin{tabular}{|l|}
60.0 \\
2.0 \\
insig \\
\end{tabular} & $\begin{array}{l}56.5 \\
1.8 \\
\text { insig } \\
\end{array}$ \\
\hline
\end{tabular}


Table (4): Mean values of some hormones level in male albino rats fed low-energy diet for 30 days treatment and 15 days recovery period.

\begin{tabular}{|c|c|c|c|c|c|c|c|}
\hline \multicolumn{2}{|c|}{ Parameters } & \multicolumn{3}{|c|}{$\begin{array}{l}\text { Treatment period } 30 \\
\text { days }\end{array}$} & \multicolumn{3}{|c|}{ Recovery period 15 days } \\
\hline & & Control & L.P.D. & L.F.D. & Control & L.P.D. & L.F.D. \\
\hline $\begin{array}{l}\text { Insulin } \\
\mu \mathrm{i}-\mathrm{u} / \mathrm{ml}\end{array}$ & $\begin{array}{l}\text { Mean } \\
\pm \\
\text { S.E } \\
\text { propability }\end{array}$ & $\begin{array}{l}60.1 \\
0.9\end{array}$ & $\begin{array}{l}55 \\
0.7 \\
\mathrm{P}< \\
0.01 \\
\end{array}$ & $\begin{array}{l}56.0 \\
0.6 \\
P<0.05\end{array}$ & $\begin{array}{l}59.0 \\
0.7\end{array}$ & $\begin{array}{l}65.2 \\
0.6 \\
P<0.01\end{array}$ & $\begin{array}{l}60.1 \\
0.4 \\
\text { insig }\end{array}$ \\
\hline $\begin{array}{l}\text { Leptin } \\
\mathrm{ng} / \mathrm{ml}\end{array}$ & $\begin{array}{l}\text { Mean } \\
\pm \\
\text { S.E } \\
\text { propability }\end{array}$ & $\begin{array}{l}3.5 \\
0.18\end{array}$ & $\begin{array}{l}3.4 \\
0.20 \\
\text { insig }\end{array}$ & $\begin{array}{l}2.5 \\
0.1 \\
\mathrm{P}<0.01\end{array}$ & $\begin{array}{l}3.5 \\
0.2\end{array}$ & $\begin{array}{l}3.2 \\
0.3 \\
\text { insig }\end{array}$ & $\begin{array}{l}3.0 \\
0.2 \\
\text { insig }\end{array}$ \\
\hline $\begin{array}{l}\text { Testost } \\
\text { erone } \\
\mathrm{ng} / \mathrm{ml}\end{array}$ & $\begin{array}{l}\text { Mean } \\
\pm \\
\text { S.E } \\
\text { propability }\end{array}$ & $\begin{array}{l}0.5 \\
0.01\end{array}$ & $\begin{array}{l}0.4 \\
0.02 \\
\mathrm{P}< \\
0.01\end{array}$ & $\begin{array}{l}0.25 \\
0.01 \\
\mathrm{P}<0.01\end{array}$ & $\begin{array}{l}0.45 \\
0.03\end{array}$ & $\begin{array}{l}0.40 \\
0.02 \\
\text { insig }\end{array}$ & $\begin{array}{l}0.30 \\
0.03 \\
\mathrm{P}<0.05\end{array}$ \\
\hline
\end{tabular}


Somaia Z. A. Rashed

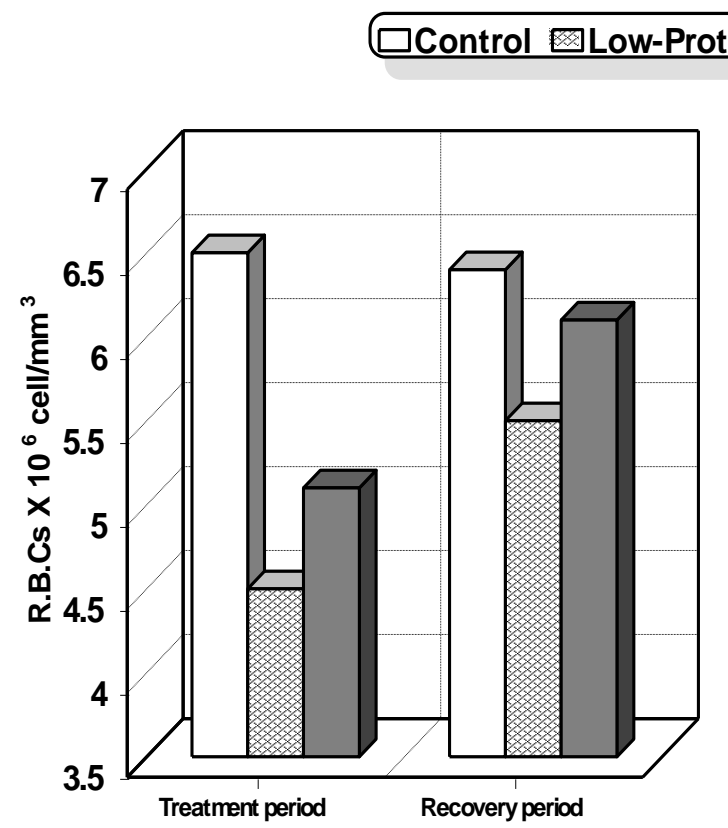

R.B.Cs

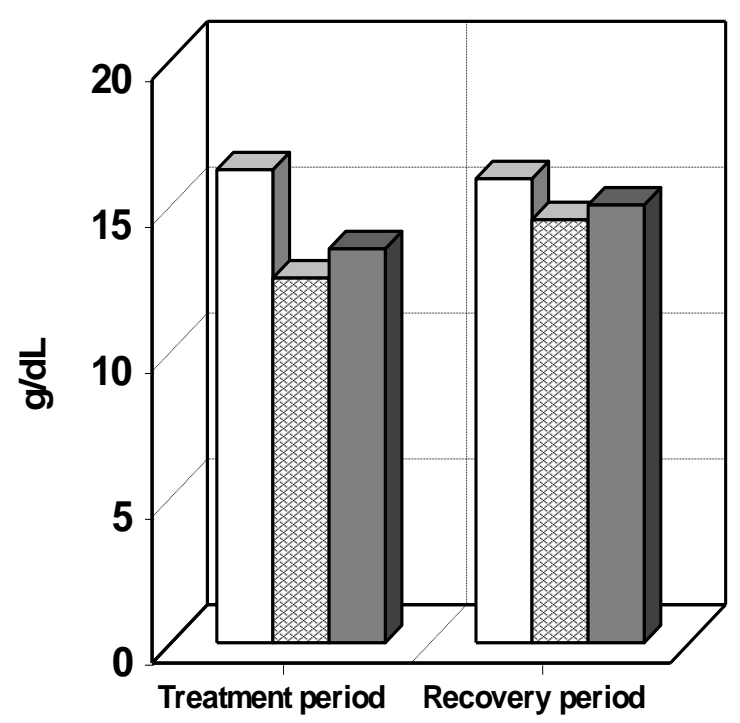

$\mathrm{Hb}$
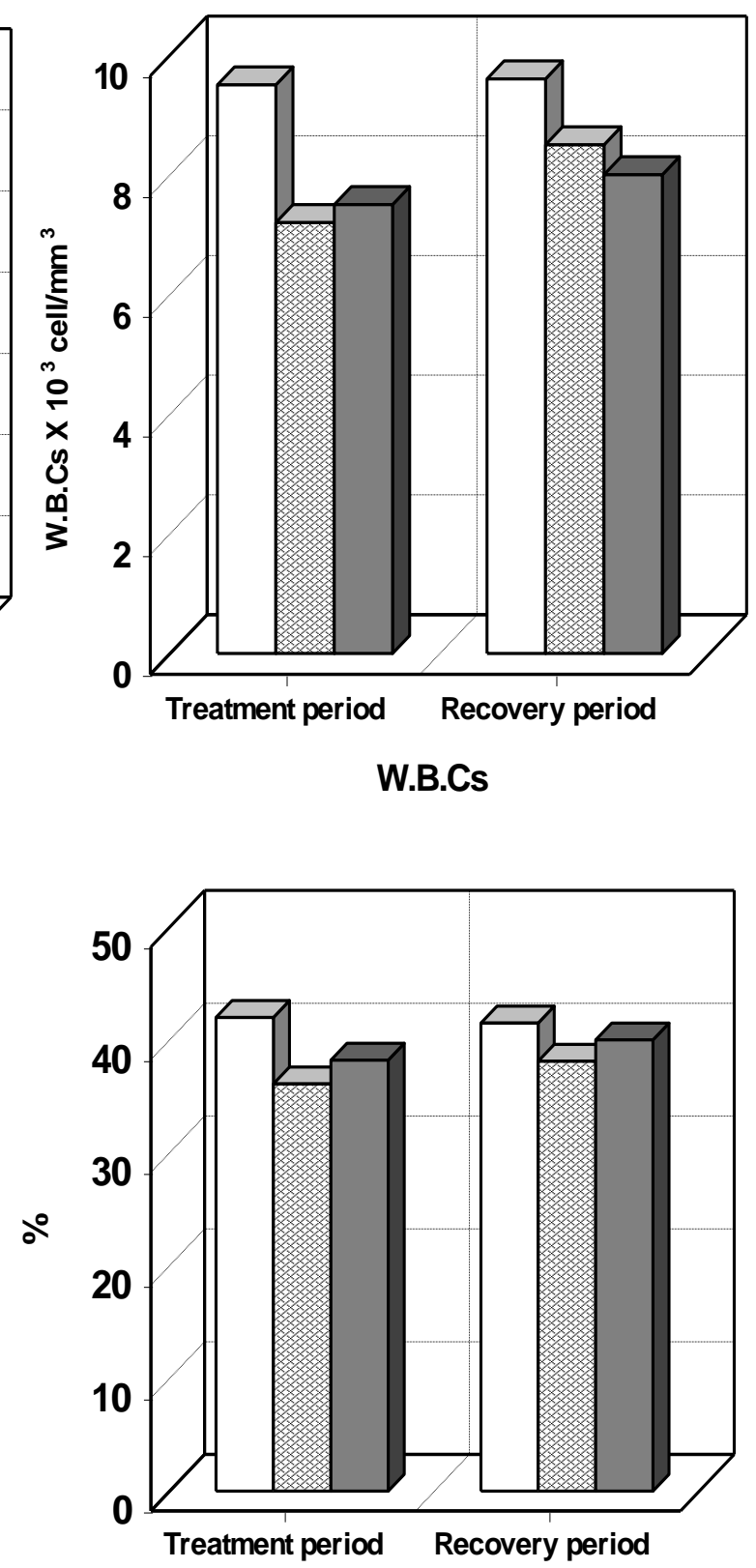

Hct

Fig.(1) Diagrammatic representations of some hormonesparameters of male albino rats fed on Low-protein and Low-fat diet for $\mathbf{3 0}$ days treatrnent and $\mathbf{1 5}$ days recovery periods. 
Changes In Some Haematological And Biochemical Parameters
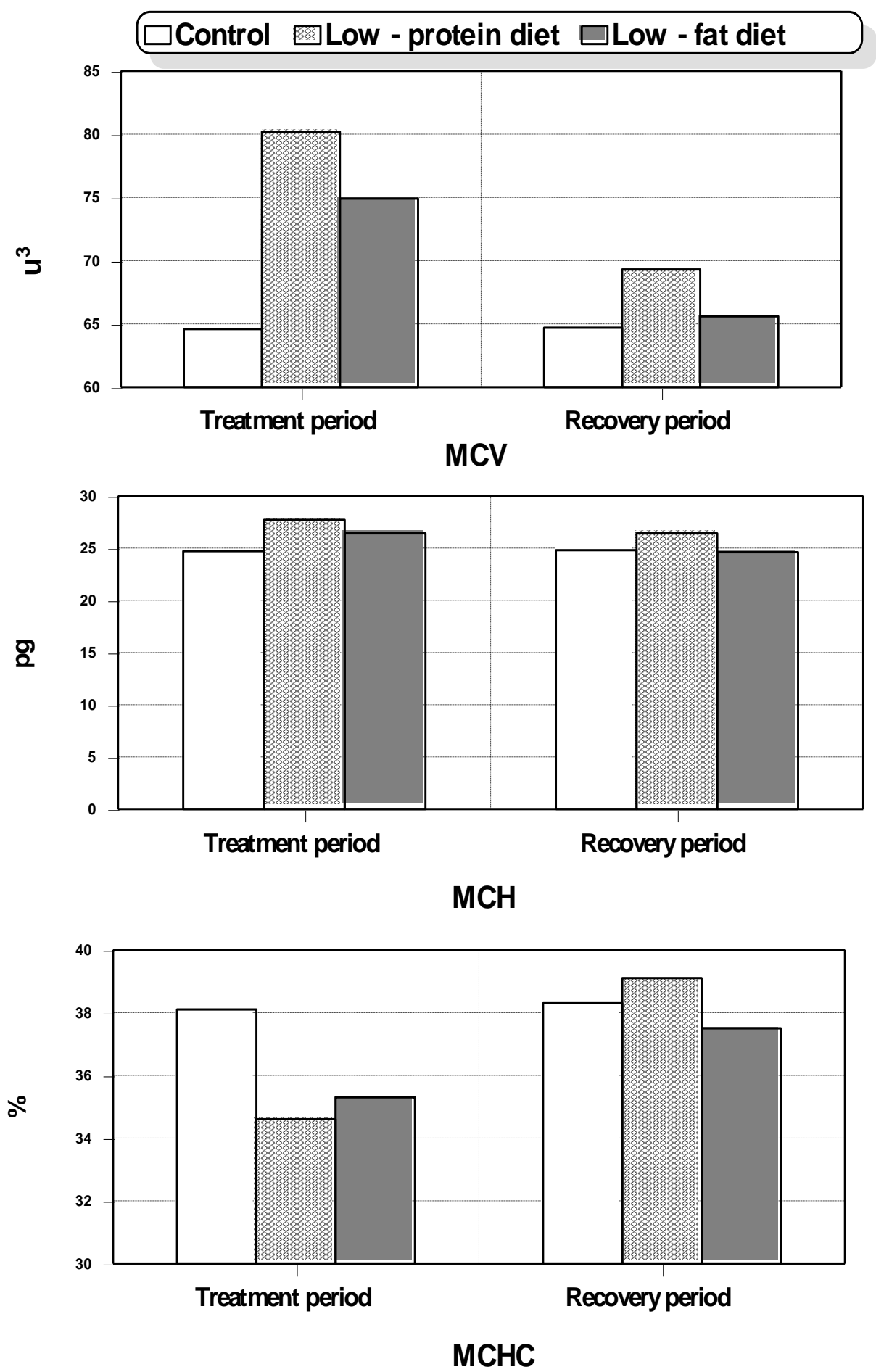

Fig.(2) Diagrammatic representations of some eryhrocyte indicies of male albino rats fed on Low-protein and Low-fat diet for 30 days treatrnent and 15 days recovery periods. 
Somaia Z. A. Rashed
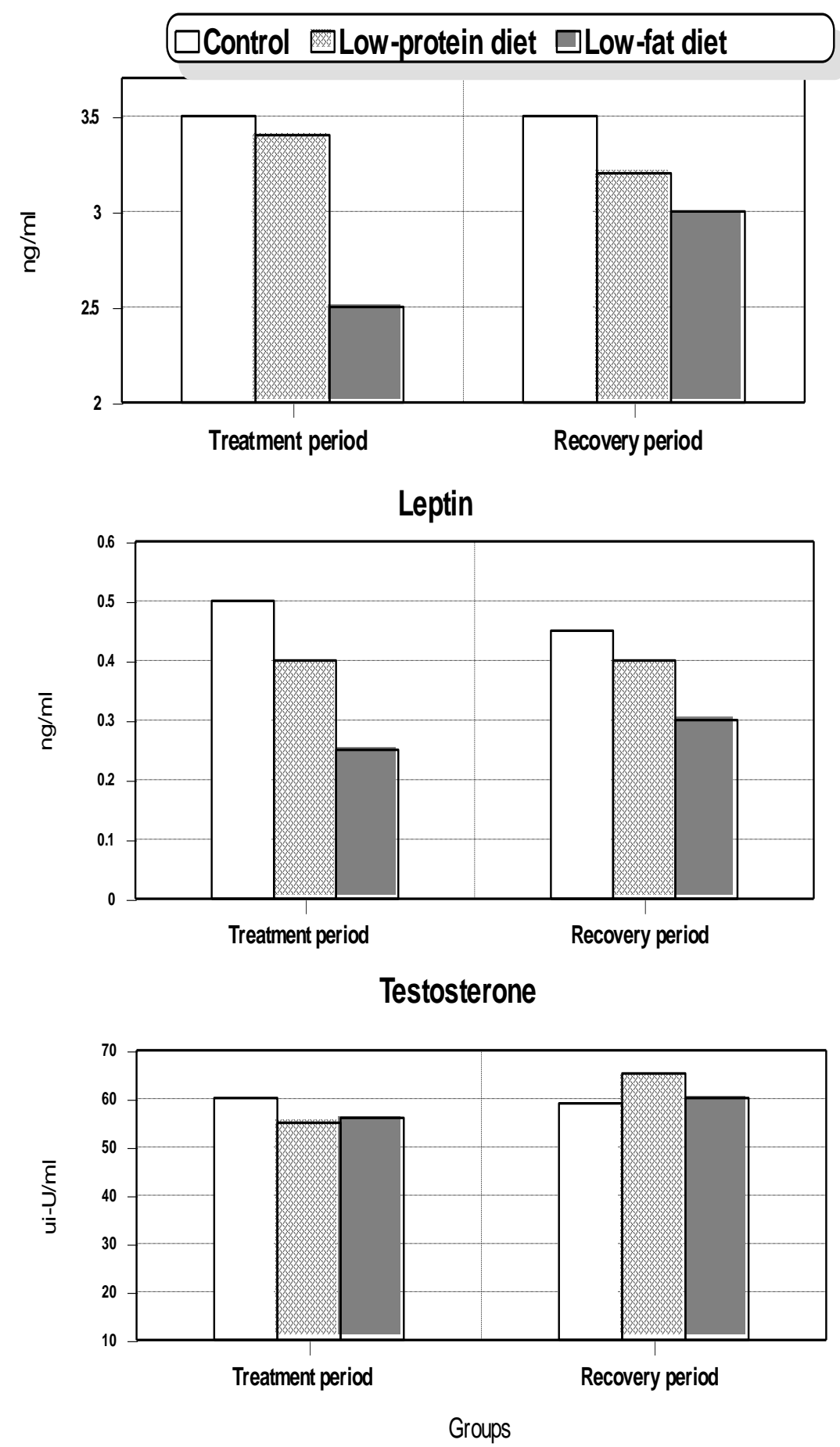

Insulin

Fig.(3) diagrammatic representations of some hormones of male albino rats fed on Low-protein diet and Low - fat diet for 30days treatment and 15 days recovery periods 
Changes In Some Haematological And Biochemical Parameters
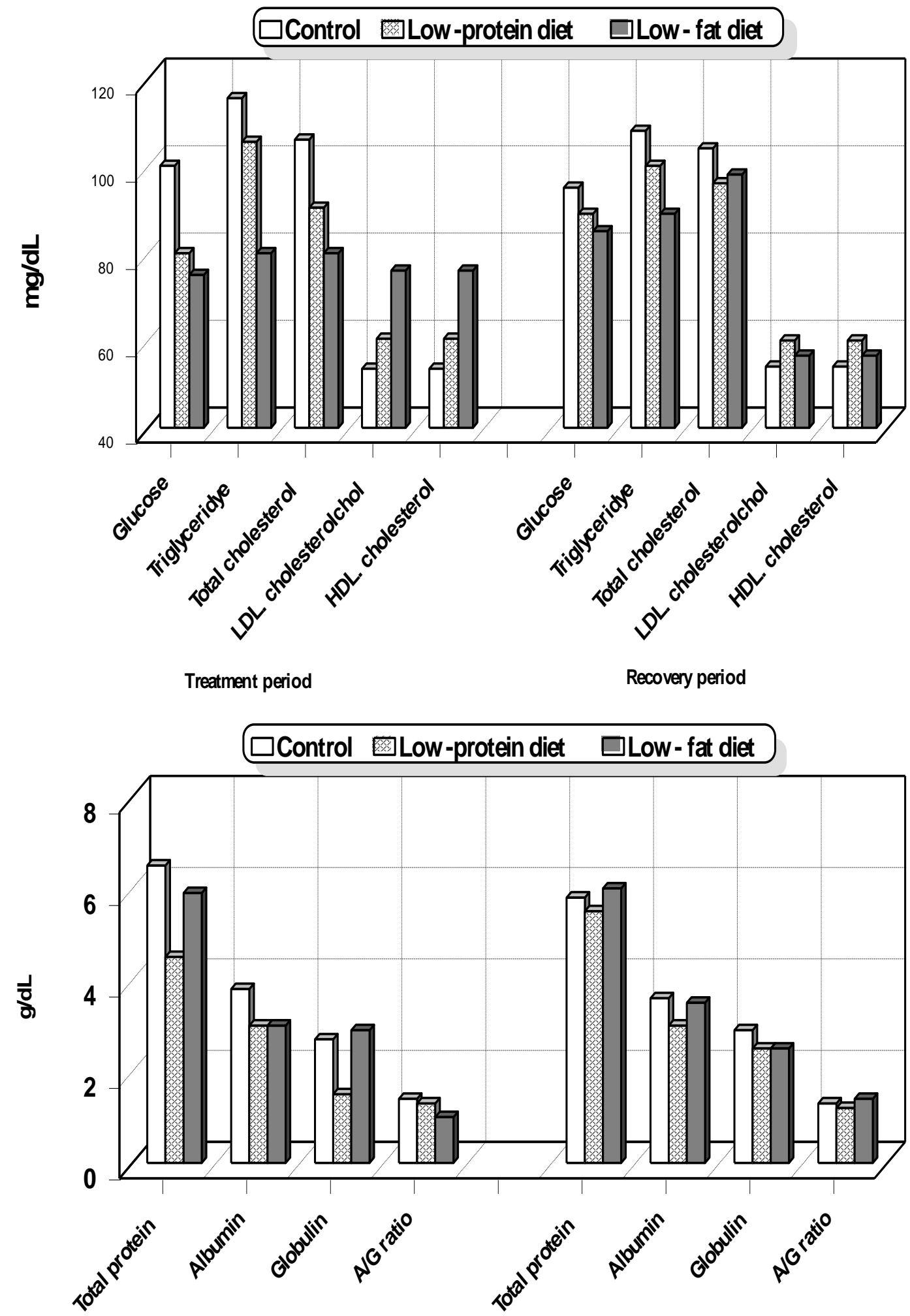

Treatment period

Recovery period

Fig.(4) diagrammatic representations of some biochemical parameters of male albino rats fed on Low - protein diet and Low - fat diet for 30 days treatment and 15 days recovery periods 


\section{Somaia Z. A. Rashed}

التغير ات فى بعض المعايير الدموية والقياسات البيوكيميائية

فى الفئران البيضاء إستجابة لوجبة منخفضة الطية الطاقة

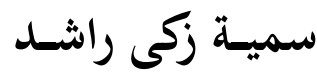

\section{قسم علم الحيون - كلية العلوم - جامعة طنطا}

لقد تم دراسة تأثير وجبة منخفضة الطاقة (دهون منخفضة الطاقة أو بروتينات منخفضة

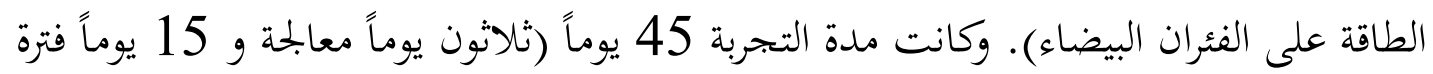
إستشفاء). لقد تم حساب زيادة أو نقص وزن الجسم وتم حساب صورة دم كاملة وتشمل كرات

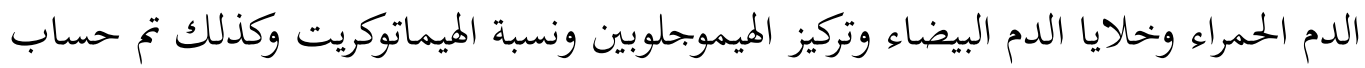
مؤشرات كرات الدم الحمراء. - ماء.

وقد أجرى قياس بعض القياسات البيوكيميائية ومنها الجلوكوز ،، البروتين الكلى والألبيومين

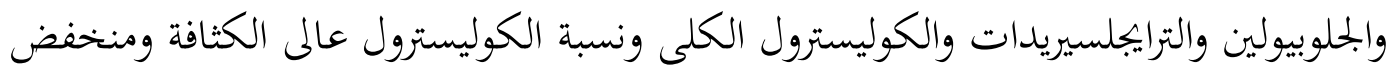
الكثافة بالإضافة إلى قياس بعض الهرمونات منها هرمون الأنسولين والتستو ستيرون وهرمون الليبتين. وقد تم قياس كل القياسات السابقة في مصل دم الفئران البيضاء فى هاية التجربة وفترة الإستشفاء.

وقد لوحظ إنخفاض فى وزن الجسم فن البمموعة التى تغذت على عليقة منخفضة الدهون

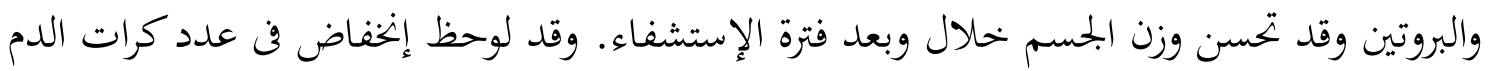

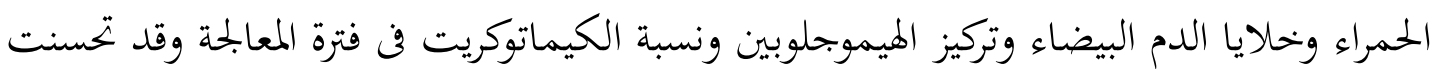
أنثاء وبعد فترة الإستشفاء.

وقد تأثر كل من البروتين الكلى والألبيومين والجلوبيولين تأثراً معنوياً أثناء تغذية الفئران البيضاء على عليقة منخفضة المحتوى الدهنى أو البروتينى. أثناء المعالجة بالمقارنة بالمجموعة الضابطة

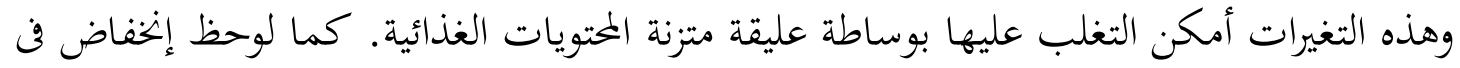
معدل الجليسريدات الثلاثية والكوليسترول الكلى والكوليسترول عالى ومنخفض الكثافة في

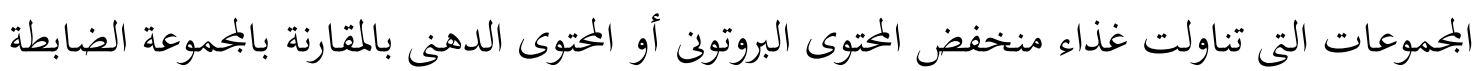

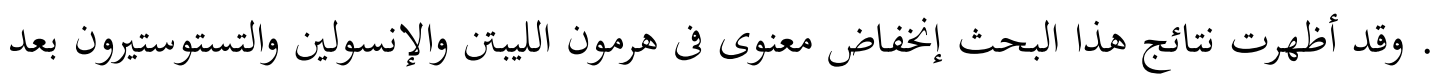

$$
\text { فترة المعالجة (30 يوم) وبعد فترة الإستشفاء (15 يوم). }
$$

